\title{
A 15-year-old boy presented with large cerebriform hyperpigmented plaque over scalp
}

\author{
Yasmin Ara Zaman, Shourav Dutta, Swarna Tribedi, A. T. M Asaduzzaman, Harasit Kumar Paul, \\ Bishnu Pada Dey and Md. Nazrul Islam
}

\begin{tabular}{|c|c|}
\hline \multicolumn{2}{|l|}{ Article Info } \\
\hline \multicolumn{2}{|c|}{$\begin{array}{l}\text { Department of Dermatology and Vene- } \\
\text { reology, Faculty of Medicine, Banga- } \\
\text { bandhu Sheikh Mujib Medical Universi- } \\
\text { ty, Shahbag, Dhaka, Bangladesh (YAZ, } \\
\text { SD,ST, ATMA, HKP); Department of } \\
\text { Pathology, Faculty of Basic Science and } \\
\text { Paraclinical Science, Bangabandhu } \\
\text { Sheikh Mujib Medical University, } \\
\text { Shahbag, Dhaka, Bangladesh (BPD); } \\
\text { Department of Radiology and imaging, } \\
\text { Faculty of Medicine, Bangabandhu } \\
\text { Sheikh Mujib Medical University, } \\
\text { Shahbag, Dhaka, Bangladesh (MNI) }\end{array}$} \\
\hline \multicolumn{2}{|c|}{$\begin{array}{l}\text { For Correspondence: } \\
\text { harasit_paul@yahoo.com }\end{array}$} \\
\hline $\begin{array}{l}\text { Received: } \\
\text { Accepted: } \\
\text { Available Online: }\end{array}$ & $\begin{array}{l}5 \text { November } 2019 \\
18 \text { February } 2020 \\
19 \text { February } 2020\end{array}$ \\
\hline \multicolumn{2}{|c|}{$\begin{array}{c}\text { ISSN: } 2224-7750 \text { (Online) } \\
\text { 2074-2908 (Print) }\end{array}$} \\
\hline \multicolumn{2}{|c|}{ DOI: 10.3329/bsmmuj.v13i1.45212 } \\
\hline \multirow{2}{*}{\multicolumn{2}{|c|}{$\begin{array}{l}\text { Keywords: Cerebriform hyperpigment- } \\
\text { ed; Plaque; Scalp } \\
\text { Cite this article: } \\
\text { Zaman YA, Dutta S, Tribedi S, Asaduz- } \\
\text { zaman ATM, Paul HK, Dey BP, Islam MN. } \\
\text { A 15-year-old boy presented with large } \\
\text { cerebriform hyperpigmented plaque } \\
\text { over scalp. Bangabandhu Sheikh Mujib } \\
\text { Med Univ J. 2019; } 12: 18-21 \text {. }\end{array}$}} \\
\hline & \\
\hline \multicolumn{2}{|c|}{$\begin{array}{l}\text { Copyright: } \\
\text { The copyright of this article is retained } \\
\text { by the author(s) [Atribution CC-By } 4.0 \text { ] }\end{array}$} \\
\hline $\begin{array}{l}\text { Available at: } \\
\text { www.banglajol.inf }\end{array}$ & \\
\hline
\end{tabular}

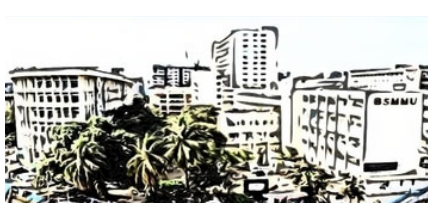

\section{Presentation of Case}

Dr. Yasmin Ara Zaman: A 15 -year-old boy $4^{\text {th }}$ issue of a non-consanguineous parents presented with a history of multiple plaques and patches on the scalp, trunk, upper and lower extremities since birth. Initially, the plaques and patches were smaller in sizes, dark brown in color, painless and non-pruritic. Since $4^{\text {th }}$ year of his age, these plaques start increasing in size and color turned into black gradually (Figure 1). The lesion on the scalp became a giant cerebriform plaque that involved left parietal region. Lesions on the trunk, upper and lower extremities became polysized and polyshaped hyperpigmented papules and nodules. He had no history of headache or seizure. His vision and hearing were normal. He had no evidence of mental retardation. His bladder and bowel habits were normal.

His built, nutrition and vitals were normal. There was a giant cerebriform plaque over the left parietal extending from the midline of forehead in front to the midline of occiput behind. There were multiple hyperpigmented papules and nodules of various size and shape located over trunk, upper and lower extremeties. Lesions were firm, nontender and the temperature over lesions was normal. A left post auricular lymph node was enlarged, $3 \times 2$ $\mathrm{cm}$ in size, firm, nontender, movable, not fixed with underlying structure or overlying skin. Examinations of the cardiovascular gastrointestinal, respiratory and nervous system revealed no abnormality.

Laboratory data revealed normal complete blood count, random blood sugar, serum alanine transaminase, serum creatinine, urine $\mathrm{R} / \mathrm{E}$, bleeding time and clotting time.

The smear of fine needle aspiration from the left postauricular lymph node showed lymphocytes at various stages of maturation along with few histiocytes. No granuloma or malignant cell

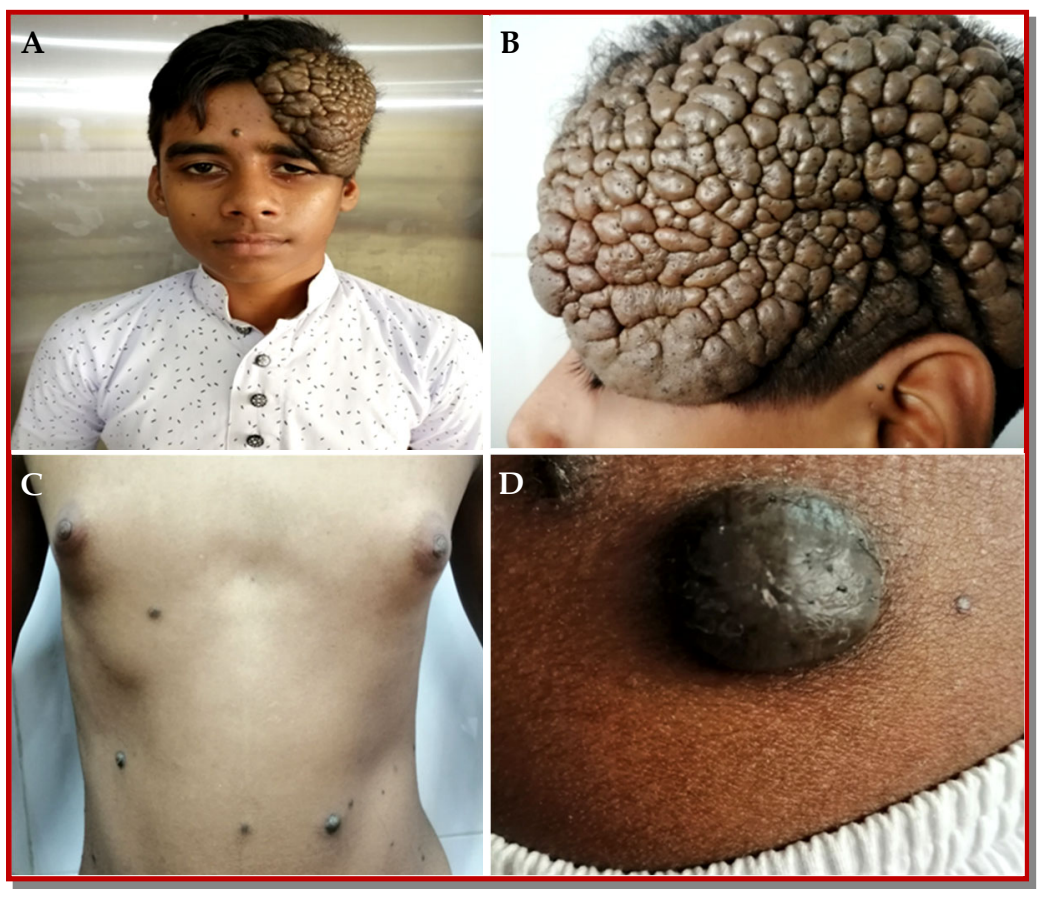

Figure 1: Giant cerebriform plaque over left parietal extending from the midline of forehead in front to the midline of occiput behind (A and B) ; Multiple hyperpigmented polysized papules and nodules over trunk $(C$ and $D)$ 


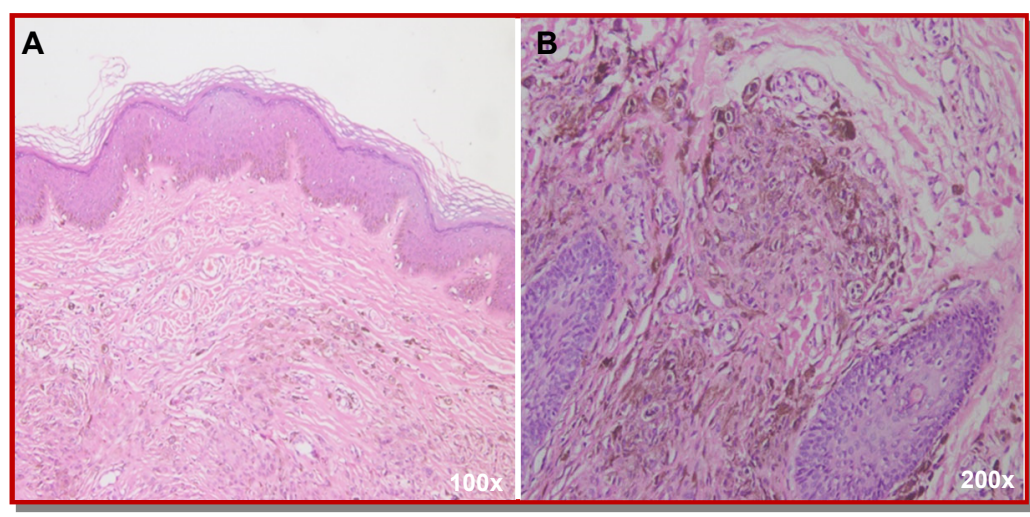

Figure 2: Mild hyperkeratosis, nests of nevus cells in the basal layer and in dermis extending to the deep reticular dermis, periadnexal and perineural areas (A and B)

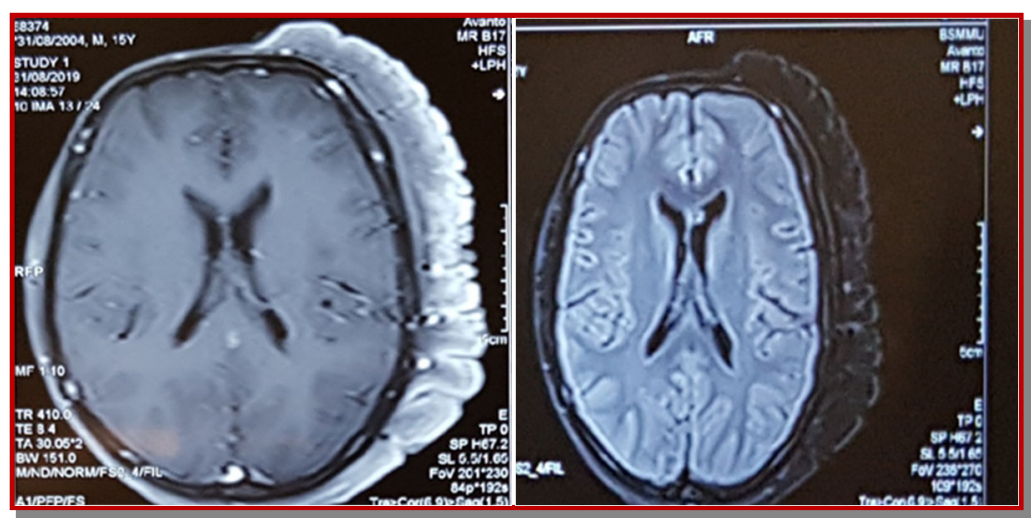

Figure 3: Magnetic resonance imaging shows soft tissue growth at scalp overlying left fronto-temporo-parleto-occipital region in two different sections

was seen. It was diagnosed as reactive lymphadenitis.

X-Ray chest posteroanterior view and ultrasonography of whole abdomen were normal. X-ray skull occipito-frontal and lateral view revealed a large lobulated soft tissue opacity on scalp overlying left parietal and occipital region. There was sclerosis of the left parietal bone.

Skin biopsy was done and specimens were collected from two sites from the lesion on scalp and trunk. Histopathologic findings of both samples revealed mild hyperkeratosis, nests of nevus cells in the basal layer and in dermis extending to the deep reticular dermis, peri-adnexal and perineural areas (Figure 2). It was diagnosed as congenital melanocytic nevus.

Magnetic resonance imaging were taken (axial T1WI, T2WI and T1Wl contrast; coronal T2WI, T1W1 contrast; sagittal T1W1 and T1W1 contrast; FLAIR and DW Image) (Figure 3). There was diffuse lobulated T1WI iso, T2WI and FLAIR hyperintense lesion at the left side of scalp overlying left fronto-temporo-parieto-occipital region and left side of the forehead. The lesion crosses the midline in its posterior aspect. No restricted diffusion was seen on DWI. After IV contrast (Gd-DTPA) administration, strong homogenous enhancement was noted. No abnormal signal change was there in the underlying bone. Post auricular (about $15 \times 0.8 \mathrm{~mm}$ ) and intraparotid $(12 \times 0.8 \mathrm{~mm})$ enlarged lymph nodes were present. The ventricles were of normal size, configuration and position for a patient of this age. Extra ventricular cerebrospinal fluid spaces and basal cisterns were unremarkable. The brain stem, cerebellum, sella, parasellar structures and orbits revealed no abnormality. Paranasal sinuses were normal.

\section{Provisional Diagnosis}

Congenital melanocytic nevus

\section{Differential Diagnosis}

\section{Cutis verticis gyrata}

Dr. Harasit Kumar Paul: Cutis verticis gyrata is a condition where scalp skin is hypertrophied and folded as parallel or gyrate folds anteriorly to posteriorly. The lesions look like cerebral gyri.1 Males are commonly affected with primary disease. So, cutis verticis gyrata may be a differential diagnosis. But the affected scalp appears normal on histology in cutis verticis gyrata.2 There are reports that congenital melanocytic nevus may be present in association with cutis verticis gyrata. $\frac{3}{-}$

\section{Proteus syndrome}

Dr. A. T. M. Asaduzzaman: Cerebriform lesion may occur here but it is in the form of cerebriform plantar hyperplasia. There may be partial gigantism of the hands and feet. Multiple systems may be involved and there may be multifocal overgrowth of tissues. .4 This may be manifested by hemangiomas, lipomas, lipohypoplasia, linear verrucous epidermal nevi, patchy dermal hypoplasia, macrocephaly, hyperostosis, muscular hypoplasia, and hypertrophy of the long bones. 5 All are absent here.

Dr. Asaduzzaman: Can it be a case of blue rubber bleb nevus syndrome?

Dr. Zaman: Blue rubber bleb nevus syndrome is an anomaly of vascular system, may affect the skin, soft tissues, and gastrointestinal tract. Any of the tissues may be affected. The skin lesions are generally small, less than 1-2 cm in diameter, a few to hundreds in number and blue to purple in color. When there is gastrointestinal involvement, the patient may have history of recurrent gastrointestinal bleeding and repeated blood transfusions. 6 In blue rubber bleb nevus syndrome characteristic symptom is nocturnal pain. Skin lesions are soft and bluish in color located mainly 
on the trunks and arms. The lesions can be emptied by firm pressure. 7 These features are absent here.

Dr. Shourav Dutta: Cylindroma (turban tumor) should be a consideration.

Dr. Paul: This is a benign neoplasm of adnexal origin. There may be single or multiple plaques or nodules located usually on the scalp but may be on the neck, trunk and genitalia. Multiple nodules on scalp may enlarge and coalesce to form giant mosaic plaques referred to as turban tumor..-10 Turban tumor itself or as a part of Brooke-Spiegler syndrome may have clinical similarity with the present case.

\section{Dr. Zaman's Diagnosis}

Congenital melanocytic nevus

\section{Discussion}

Dr. Paul: Congenital melanocytic nevus is a pigmented melanocytic nevus present at birth. Initial lesion may be pigmented patch. 11 This is a benign condition. This is a clinical condition where there is a non -neoplastic proliferation of abnormal mixtures of tissue's normal components. $1-2 \%$ of newborns may be affected with single lesion of congenital melanocytic nevus with a female to male ratio of 1.2:1. Multiple lesions may be there. Sometimes skin lesions may not present at birth, develop at any time after birth and continue to grow over time. Some cases may be associated with other diseases like neurofibromatosis type 1.12,13 According to their sizes congenital melanocytic nevus are classified as small $(<1.5 \mathrm{~cm})$, medium $(1.5-19.9 \mathrm{~cm})$ and large or giant naevi $(>20 \mathrm{~cm}) \cdot \underline{11}$

Dr. Lutfar Rahman Rahat: Is there any genetic linkage in the etiology?

Dr. Zaman: The disease is associated with somatic mutation in utero. 12 A study reported that multiple congenital melanocytic nevus and congenital melanocytic nevus syndrome are usually caused by mutations in the NRAS gene. $\underline{14}$

Dr. Md. Mostaque Mahmud: Is there any chance of developing malignancy?

Dr. Zaman: Yes, there is a risk of developing malignancy. Malignant melanoma may develop in approximately $6 \%$ of cases of giant naevi. Melanoma commonly develops in early ages, 50\% by the age of two years and $80 \%$ by the age of seven years. There is an increased risk of malignancy where size of the nevus is large $(>50 \mathrm{~cm})$, located at axial locations like trunk, head and neck and where multiple lesions are there. $.11,15$

Dr. Swarna Tribedi: How will you treat the case?
Dr. Zaman: No drug will help him. Cryotherapy is suitable for small lesions that are present on the trunk, upper and lower extremities. For lesions on the scalp serial excision and reconstruction with skin grafting, tissue expansion, local rotation flaps and free tissue transfer are the options. $\underline{11}$

Dr. Abu Hena Chowdhury: Is there any chance of recurrence after surgery?

Dr. Paul: Recurrence in patients may be due to the residual nevus cells in the lower dermis. Excision of the nevus cells in its full depth is the way to prevent recurrence. Jain et al. (2008) $\underline{16}$ reported that they underwent serial excision of five patients with congenital melanocytic nevi revealed no sign of recurrence even after 1-1.5 years of follow-up.

Dr. A. K. M. Rezaul Haque: Will the surgery eliminate the possibility of developing malignancy?

Dr. Zaman: When there is involvement of deeper tissues like leptomeninges, excisions may not eliminate the risk for developing melanoma.11

\section{Final Diagnosis}

Congenital melanocytic nevus

\section{References}

1. Yang JJH, Sano DT, Martins SR, Tebcherani AJ, Sanchez APG. Primary essential cutis verticis gyrata-Case report. An Bras Dermatol. 2014; 89: 326 -28 .

2. Ko CJ. Dermal Hypertrophies and Benign Fibroblastic/Myofbroblastic Tumors. In: Goldsmith LA, Katz SI, Gilchrest BA, Paller AS, Leffell DJ, Wolf K, editors. Fitzpatrick's Dermatology in General Medicine. $8^{\text {th }}$ ed. New York: McGraw-Hill; 2012, p 717.

3. Polan S, Butterworth T: Cutis verticis gyrata: A review with report of seven new cases. Am J Ment Defic. 1953; 57: 613-31.

4. Salati SA. Proteus syndrome. J Pioneer Med Sci. 2017; 7: 24-26.

5. James WD, Berger TG, Elston DM. Andrews' Diseases of the skin. Clinical dermatology. $11^{\text {th }}$ ed. Saunders Elsevier; 2011, p 546-47.

6. Fishman SJ, Smithers CJ, Folkman J, Lund DP, Burrows PE, Mulliken JB, Fox VL. Blue rubber bleb nevus syndrome: Surgical eradication of gastrointestinal bleeding. Ann Surg. 2005; 241: 52328.

7. James WD, Berger TG, Elston DM. Andrews' Diseases of the skin. Clinical dermatology. $11^{\text {th }}$ ed. Saunders Elsevier; 2011, p 577.

8. McCalmont TH, Pincus LB. Adnexal Neoplasms. 
In: Bolognia JL, Schaffer JV, Cerroni L, editors. Dermatology. $4^{\text {th }}$ ed. Elsevier; 2018, pp 1948-49.

9. Chauhan DS, Guruprasad Y. Dermal cylindroma of the scalp. Natl J Maxillofac Surg. 2012; 3: 59-61.

10. Patra S, Sethuraman G, Kumar R. Turban tumor: A classical presentation of Brooke-Spiegler syndrome. Indian Dermatol Online J. 2018; 9: 284-85.

11. Das SK, Amarendra M, Subudhi M. Giant congenital melanocytic nevi: A case report. J Clin Diagn Res. 2013; 7: 154-55.

12. Kinsler VA, Sebire NJ. Congenital naevi and other developmental abnormalities affecting the skin. In: Griffiths CEM, Barker J, Bleiker T, Chalmers R, Creamer D. (eds). Rook's Textbook of dermatology. 9th ed. John Wiley \& Sons, Ltd, 2016, p 75.9-75.11.

13. Pai VG, Rao GS. Congenital cerebriform melano- cytic naevus with cutis verticis gyrata. Indian J Dermatol Venereol Leprol. 2002; 68: 367-68.

14. Kinsler VA, Thomas AC, Ishida M, Bulstrode NW, Loughlin S, Hing S, Chalker J, McKenzie K, Abu-Amero S, Slater O, Chanudet E, Palmer R, Morrogh D, Stanier P, Healy E, Sebire NJ, Moore GE. Multiple congenital melanocytic nevi and neurocutaneous melanosis are caused by postzygotic mutations in codon 61 of NRAS. J Invest Dermatol. 2013; 133: 2229-36.

15. Rhodes AR, Melski JW. Small congenital nevocellular nevi and the risk of cutaneous melanoma. J Pediatr. 1982; 100: 219-24.

16. Jain VK, Singhi MK, Goyal R. Serial Excision of Congenital Melanocytic Nevi. J Cutan Aesthet Surg. 2008; 1: 17-18. 